\title{
URBAN FOREST ECOLOGY: CONCEPTUAL POINTS OF DEPARTURE
}

\section{by Rowan A. Rowntree}

In this special issue of the Journal of Arboriculture, the field of urban forest ecology is substantially advanced by a set of studies conducted in Sacramento, California, the capital of the largest, most urbanized, and one of the fastest-growing states in the U.S. Sixteen years ago in the introduction to the first textbook on urban forestry, Grey and Deneke (1978) recommended that cities should soon employ "the concept of integrated urban forest ecosystem management." In the years since this suggestion, most cities barely have been able to keep up with pruning and removal, let alone manage their resource as an ecosystem. It is even more difficult to embrace an ecological approach when it is perceived-as it is by many-that urban forestry lacks intellectual roots in ecology. Yet there is almost half a century of thoughtful, scholarly, scientific writings that are the natural antecedents to contemporary urban forest ecology. This introduction to the special issue illustrates the evolution of the ecological view in urban forestry and discusses several useful concepts that have emerged.

Abstract. The ecological view in urban forestry evolved from diverse roots beginning over 100 years ago and is currently expressed in formal programs of research and practice. Among the most useful concepts in urban forest ecology are structure, function, diversity, dominance, mosaic-gradients, and ecosystems. These concepts assist in understanding changes in ecological states that produce changes in the distribution of benefits and costs. The ecological history of urban forestry provides these concepts as points of departure for two special issues of the Journal of Arboriculture devoted to the Sacramento urban forest ecosystem.

Keywords: concepts, ecological history

\section{Evolution of Urban Forestry's Ecological Roots}

George Perkins Marsh's Man and Nature (1864) is recognized as "the first great work of synthesis in the modern period to examine in detail man's alteration of the face of the globe" (Thomas 1956a, p. xxix). His largest chapter, "The Woods," is one-third of the book; thus, foresters and conservationists acknowledge Marsh as an important point of departure. Marsh looked to the "New School of Geographers" $(1864$, p. 13) as his own intellectual inspiration, and this reliance on Humboldt, Ritter, and Guyot produced a balanced view of human agency. Most references to Marsh emphasize his concern over human despoilation of the land. But a theme pertinent to the evolution of urban forestry stems from Marsh's belief that "by understanding the nature of his impact on the environment, man might learn to change the face of he earth in rational, constructive fashion" (Thomas 1956a, p. xxix). Indeed, in 1847, he praised Vermont farmers for filling "with light and life, the dark and silent recesses of our aboriginal forests" (Lowenthal 1965). He was sensitive to the number and arrangement of trees in the inhabited landscape and, one could reasonably infer, to the capability of humans for creating a pleasant and useful woods to enhance places of habitation. This influential Vermonter may have been one of the inspirations for the College of Forestry at Syracuse to initiate, in 1914 , teaching and research in city forestry (Herrington 1980).

In June 1955, 53 of the world's scholars on the subject of human-nature relations convened in Princeton, New Jersey, in honor of Marsh's foresight. The result was one of the best anthologies ever compiled on the subject of land stewardship: Man's Role in Changing the Face of the Earth (Thomas 1956). Two scholars in this symposium had important thoughts about urban vegetation. Lewis Mumford concluded that early cities displaced nature under "the illusions of selfsufficiency and independence and of the possibility of physical continuity without conscious renewal" (Mumford 1956, p. 387). This, in his view, "undermined the whole social and economic structure" of these cities. Edgar Anderson argued that the human ecology of urban vegetation, in 
its rich and varied dimensions, is a most legitimate field of inquiry and should be a focus of scientific study and public action (Anderson 1956).

Five years later, the renowned French geographer Jean Gottmann put any ambivalence about this subject to rest by confirming the existence of the urban forest in his widely read book, Megalopolis. He documented that trees are an integral part of the fabric of the eastern seaboard's urban connurbation (Morel and Gottman 1961). By the time Megalopolis was in bookshops, ecologists were organizing a symposium to modify concepts and methods from their field to study The Suburban Forest (Waggoner and Ovington 1962). The proceedings of that conference are a rich and credible precedent for thinking about the urban forest ecologically.

At the turn of the decade, Li (1969) and Stearns (1971) called for the formation of a comprehensive field they described as "urban botany," and an important symposium gave identity to the new field of urban forestry (University of Massachusetts 1971). In 1972, Detwyler offered a taxonomy of vegetation highlighting the existence of the urban forest (Detwyler 1972). Three years later, the first original research on urban forests was published. In America, McBride and Jacobs (1975) and Schmid (1975) described the structure and evolution of two urban forests using different approaches. That same year in Japan, the ecologist Numata published the first of what would become a long series of studies on vegetation in urban ecosystems (Numata 1975).

By the late 1970s, urban forestry's intellectual roots had taken hold, and a rich array of international field reports had appeared. Those studies of wall vegetation (Segal 1969; Woodell 1979), bryophytes, lichens, mosses, and mushrooms (Leblanc and Rao 1973; Taoda 1977; Seaward 1979) still enrich our knowledge of the total urban vegetation mix. John Andresen offered a lengthy anthology from Canada (Andresen 1976), and Sukopp et al. (1979) published research on the early successional flora of bombed lands in German cities. The 1970s ended with the first National Urban Forestry Conference, which brought together 103 papers and 33 posters from the physical, biological, and social sciences, including important participants from the urban planning and city management professions (Hopkins 1980). State and regional conferences also flourished in the closing years of this seminal decade.

In the 1980s, a growing literature spoke directly to the question of using ecology in urban forestry. Two special issues (23 papers) of the international journal Urban Ecology were devoted to urban forest structure and function (R.A. Rowntree 1984a, 1986). These were followed by a special issue of Landscape and Urban Planning with 15 papers on methodological and management issues of urban forest ecology and how human perceptions, attitudes, and values influence the urban forest (R.A. Rowntree 1988). That same year, the second textbook on urban forestry was published (Miller 1988). This text updated and reorganized knowledge in the field and connected the many specifics of biology and management in an ecological way. The autecology of urban trees was advanced significantly by the work of Bassuk and Whitlow in 1988. (Ecophysiology research increased in importance into the next decade as part of urban forest ecology, e.g., Clark and Kjelgren 1990). The following year, O.L. Gilbert's (1989) book, The Ecology of Urban Habitats, gave a comprehensive treatment to both floral and faunal aspects of urban ecology from a British perspective.

As the 1990s began, discussion was growing about how an ecological approach could bring together scientists, citizens, policy makers, and managers. American Forests' 4th National Urban Forestry Conference provided the forum for this discussion (Rodbell 1990), and the next year the International Society of Arboriculture held a multidisciplinary Urban Forestry Research Summit in which "ecological benefits" were ranked as the highest priority for study (International Society of Arboriculture 1991). The summit helped give formal credibility to the concept of the urban forest as an ecological system. At the 5th National Urban Forestry Conference, a hopeful ecological vision was articulated (Sampson and 
Rowntree 1992), and by 1995, leaders of the urban forestry movement in the United States were ready to institutionalize the ecological approach to their field. As a result, American Forests organized the 7th National Urban Forestry Conference with the theme "Inside Urban Ecosystems," and Gary Moll led off the proceedings with his paper on urban ecosystems analysis (Moll 1995).

Perhaps the best evidence that, by the early 1990s, an ecological approach was acceptable to decision makers was the initiation of the Chicago Urban Forest Climate Project by Mayor Richard M. Daley of Chicago with support from the U.S. Congress. This was an ecosystemoriented, three-year study of both biophysical and human elements (McPherson et al. 1994). While this study was underway, a symposium-"The Ecological City"-was held in Chicago that furthered understanding of the way humans influence and are influenced by the urban ecosystem (Platt et al. 1994). The human aspects of urban forest ecology are highlighted in this anthology by the thoughtful review of Dwyer et al. (1994), who had conducted 15 years of social science research in urban forestry from their base in Chicago.

In 1997, two events helped solidify the legitimacy of urban ecosystems and urban forest ecology. The National Science Foundation awarded major grants for Urban Long-Term Ecological Research programs in Baltimore and Phoenix, in which vegetation plays a key role. And a new international journal, Urban Ecosystems, began publication with the acknowledgment that the urban forest is integral to the urban ecosystem (Walbridge 1997).

This brief sampling unfortunately omits numerous symposia, unpublished presentations, colloquia, and published articles that add substance, depth, and breadth to urban forest ecology. However, the sample does demonstrate that urban forestry and arboriculture, together, have a solid ecological heritage in the literature. From this literature, several concepts have emerged that serve as points of departure for implementing the ecological approach. As background for this special issue, these concepts are restated and briefly discussed.

\section{Structure and Function: Foundation Con- cepts of Urban Forest Ecology}

Structure is the array of static attributes of the urban forest, the concept that asks the question "What is where?" Examples of structure include the spatial distribution of species, biomass, size, age, and condition classes-the attributes one would note in an inventory of all trees in a city. Function is the dynamic operation of the forest: how the vegetation interacts with other components of the ecosystem, including humans, and how internal and external forces change urban forest structure over time. Examples of function are the interactions between trees and their biophysical environment. These include tree physiology and exchanges of energy and matter that may affect the fauna and the atmosphere. Function includes roots breaking sidewalks in their search for nutrients, water, and gas exchange, and trees creating a moist microenvironment for insects while collecting pollutants and cooling the air. Shade is cast, allowing Homo sapiens to conserve energy. When a tree affects something else in the system, or vice versa, that is ecological function. The functions of disease and aging change forest composition over time. The functional interactions of the forest with weather and humans provide for episodic changes, such as fires and ice storms. Critical to the ecological approach is the ability to understand structure and function at different spatial and temporal scales.

At the smallest scales, ecological functioning of the urban forest begins with the interactions of individual trees with one another and with other components of the ecosystem. But how does the operation of a single tree fit into the functioning of the forest ecosystem? Answering this question ties the study of arboriculture naturally to urban forest ecology. The ecological approach integrates operations of individual trees (Heisler 1986, 1990; Yang et al. .1995) with the functioning of groups of trees or stands at the scale of the yard, block, neighborhood, planning district, census tract, city forest, urbanized-area forest, and regional forest. This process may result in an assessment of the distribution of costs and benefits within spatial and temporal hierarchies. 
Activities at each spatial or temporal scale influence activities at larger and smaller scales. Good examples of recent studies of structure are available for Oakland (Nowak 1992), Chicago (McPherson et al. 1994), and Sacramento (McPherson, in press). Until recently, a weakness in structural studies has been the absence of accurate techniques for estimating leaf area, an attribute influencing many urban forest effects. Nowak's recent review (1996) suggests improvements in leaf area estimation, but he states that difficulties remain in accurately calculating woody biomass for urban trees (Nowak 1998).

\section{Gross Structure: the Geography of Canopy Cover}

If an arborist or urban forester were to create a database for the purpose of understanding the structure of the urban forest, the first step would be to describe the spatial distribution of canopy cover. The amount and distribution of canopy cover within a city and among cities in various regions depend on the available growing space (for roots, stems, and crowns) and how people choose to fill that space with lawns, shrubs, or trees. Canopy-cover numbers averaged for entire cities are of limited value. They do not convey the important spatial variation in canopy cover within the city nor provide us with a basis for comparing urban forest structures among cities from different ecoregions or among cities with different land management, demographic, economic, and cultural histories.

Within a city, canopy cover and available growing space are generally determined by land use (R.A. Rowntree 1984b). Thus, a land-use map of a city can be the first step in explaining and managing its overall urban forest structure. The residential land-use class usually contains the largest proportion of canopy. Comparing average values among cities for this land-use class is often more helpful than comparing cities' averages from all land-use classes (Nowak et al.1996).

\section{Species Composition: Diversity and Dominance}

In plant ecology, discussions have focused on how to measure diversity and what these mea- sures mean (Barbour et al. 1980; Greig-Smith 1983). We can use diversity measures in urban forestry to augment descriptions of structure and to understand the costs of different diversity strategies. Previous studies have used conventional ecological methods such as diversity and dominance in the analysis of urban forest composition. For example, in both Menlo Park, California (McBride and Jacobs 1975), and Akron, Ohio (Whitney and Adams 1980), methods in plant ecology have been applied successfully to the urban forest. In addition, the more specialized studies of street and yard trees contain frequency and size data that can be used to construct a picture of diversity and dominance (Derrenbacher 1969; Schmid 1975; Richards and Stevens 1979).

Relative dominance is a species' percentage of the total basal area of all species. With diversity indices, relative dominance can be a measure of differences among management units in an urban forest or a means of showing how the composition of a forest is changing over time. Ecological measures can be used to compare street tree populations (McPherson and Rowntree 1989). The same approach can be used within a single urban forest comparing management units or census tracts to identify trends and patterns that influence replacement and maintenance costs.

Diversity can be an attribute of urban forest sustainability. For example, the Brookhaven National Laboratory symposium in 1969 included 20 papers exploring the validity of the hypothesis that diversity leads to stability in natural and humandominated systems (Woodwell and Smith 1969). Not surprisingly, the answer to the question rests largely on how diversity and stability are defined and in what social context they are used. Questions raised at this conference are further developed in recent books on the validity of concepts of "ecosystem health" (Costanza et al. 1992) and the elements of myth, belief, perception, symbol, and assumption in our management of nature (Botkin 1990). These inquiries help in our search for a useful definition of urban forest sustainability, a concept now very much in the public mind and one that has been examined in this journal (Clark et al. 1997). 
For urban forests, there is a level of diversity that can nurture stability if the latter is defined as a state resistant to catastrophic loss. Excessive diversity, however, may increase management costs to the point at which stability of the urban forest is jeopardized (Richards 1993). Given the current interest in preserving biodiversity in natural systems, as urban forests impinge on natural forests, the concept of biodiversity may have to be modified to judge the positive or negative values of adding exotic species to remnant presettlement forest structures.

\section{Boundaries, Mosaics, Gradients, and Linkages}

Arguments over where the urban forest ends and where the exurban forest begins have given way to a search for means to understand the mix and gradients of different structures. For example, undeveloped parcels within the urbanized area may appear in both structure and function to be nonurban forests or stands. These woods may have fully articulated vertical stratification and unbroken biochemical cycles. However, while there is little visible evidence of human influence, the current and future status of these forest patches is governed almost entirely by the invisible but powerful human processes of land speculation, regulation, taxation, and development. Therefore, their existence is largely determined by socioeconomic processes based in the urban culture. Indeed, these natural patches of forest, shrubland, or grassland are important parts of the urban forest, and they invite us to observe the interaction of the surrounding matrix with these more naturally structured forest patches.

If one of the powerful forces defining and governing urban forest structure and function is the set of urban-based land-development, landregulation, and socioeconomic processes, how do we practically define the outer boundary of the urban forest? The forces of urbanization reach far beyond the visible edge of the urbanized area. The gradient of connected patches is a concept coming into use: the urban forest is at one end of a gradient of functionally connected vegetation zones laid out across the landscape, and the boundaries between these systems may be dis- crete or fuzzy (Bradley 1984; Pouyat et al. 1995). Relationships can be seen between structural and functional characteristics inside the urban forest as well as in those relationships existing across the mosaic of connected vegetation zones (Zipperer 1993). This approach qualifies the arborist and urban forester to enter debates about, for example, the ecological consequences of a city's expansion into undeveloped wildlands, restoration of vegetation patches or zones within the city, or the consequences of urban exotics escaping into native forest stands at any place along the gradient.

\section{Changes in Structure over Time}

Everyone wants to understand change-the way things were and the way they will be tomorrow. A growing number of arborists and urban foresters are attracting attention to their programs by using old photographs to show the often startling difference in urban forest cover and composition between a time some decades ago and the present. Whether or not this is done to make a specific point (such as the need for more planting) is less important perhaps than the fact that it adds a new dimension, a richness, to our understanding and appreciation of the urban forest. McBride and Jacobs' $(1975,1979)$ studied how the structure of urban forests in two California towns compare with their presettlement forests and is a model for work that can be done anywhere. Nowak's analyses of urban forest structural change in Oakland, California, and Chicago, Illinois, is based on these studies (Nowak 1992, 1994a), and McPherson and Luttinger (this issue) provide an excellent history of the Sacramento urban forest.

Photographs of neighborhoods before and after the removal of the American elms became the focus of discussions about diversifying the urban forest to avoid epidemics. After the 1991 fire that burned over 3,000 dwellings in the Oakland hills, a dominant issue was the role of the changing urban forest and adjacent urbanwildland vegetation in the ignition and spread of the fire and what type of urban forest structure is best for a fire-prone region. Fire has historically been a part of this landscape, but before settle- 
ment, the average above-ground plant biomass of the annual grasslands was only 2 to 3 tons per acre (Allen-Diaz 1994) and allowed for lowintensity ground fires. With settlement, urban forest biomass in the portion of Oakland that burned had increased to ten times the presettlement amounts (Nowak 1993; L.B. Rowntree 1994). Once this historical picture was presented to the the public, the debate turned to understanding the human and natural dynamics of changing vegetation along the urban-to-wildland gradient where most of the recent and harmful fires have started (East Bay Hills Vegetation Management Consortium 1995).

\section{The Urban Forest Ecosystem}

Although many people still find the ecosystem concept problematic, it is an excellent framework for planning, management, and education (Yaffee 1996). The suffix "-system" implies that the concept focuses on activities, operations, and dynamics, including the interaction of components with the many fluxes of matter and energy among the soil, vegetation, faunal populations, and atmosphere (R.A. Rowntree 1994).

One danger seems to be trying to load too much into the concept. For example, if we believe it is necessary to understand the full operation of cities (including, for example, industrial activity, socioeconomic structure, and traffic flows) in order to understand the operation of cities' forests, we may become overwhelmed. The key is to focus on urban vegetation and soils as the renewable and manipulable infrastructure of the urban system by which water, energy, pollutant, and nutrient fluxes can be measured, as well as human benefits and costs associated with different urban vegetation structures and functions.

A second barrier to applying the ecosystem concept to the study of urban forests has been the misconception that ecosystems are found only in relatively untouched wildland landscapes. This notion is becoming less of a stumbling block as 1) society and science come to understand that most ecosystems on our planet have been modified by humans and 2) we learn how to model human participation in these systems. Urban forest ecology, as a science, has the potential for contributing importantly to the advancement of general ecosystem theory and management because scientists and practitioners in our field are building a credible fund of knowledge about humans as both intrinsic and extrinsic factors.

The ecosystem concept has been applied in several projects relevant to urban forestry practice and research. First, in 1993, after the Sacramento Tree Foundation had been developing urban forestry programs for ten years, this nonprofit organization brought together a regional coalition of business, research, and education organizations to explore the ecosystem concept for discussing sustainable development in the larger Sacramento region. The urban forest was conceived to be at the core of the regional ecosystem and facilitated important advances in planning, management, and education at many age levels (Tretheway 1993). Also during the early 1990 s in the Los Angeles region, the Tree People used the ecosystem concept effectively to build community and to construct an environmental accounting system that currently enables citizens, schools, and government to share comprehensive information about vegetation and environmental management of the Los Angeles Basin (Lipkis 1997).

Today, federal and state land agencies have accepted the ecosystem concept as the framework in which they will develop land-management policies (USDA Forest Service 1992, 1994; Forest Ecosystem Management Assessment Team 1993). For the first time land policy at several levels of government contains a mandate for devising management strategies that link ecosystems in urbanized and nonurbanized lands (R.A. Rowntree et al. 1993). This framework will nurture a regional ecological approach in urban forestry.

Another project created a training program on urban forest ecosystems for anyone interested in developing a full ecological approach to urban forestry (USDA Forest Service 1993). The first courses were taught in the summer of 1993; course attendance and success encouraged support for the idea that the urban forest ecosystem is a useful concept. The large sourcebook for this course is a comprehensive treatment of fundamental ecological concepts and approaches. 
The urban forest ecosystem concept is flexible enough to be applied to any city. The studies reported in this issue are a result of transferring the approach developed in Chicago (McPherson et al. 1994) to Sacramento. Both the Chicago and Sacramento projects necessarily focused on only selected functions resulting from changing forest structure. In Chicago, improved distribution of benefits and costs were estimated for changes in forest structure and the resulting changes in functions (McPherson 1994b). Those functional categories on which the Chicago study focuses are energy conservation (McPherson 1994a), carbon sequestering (Nowak 1994b), and air pollution reduction (Nowak 1994c). In Sacramento, a long-term research and monitoring program (McPherson 1993) is being initiated that will allow scientists, practitioners, nonprofit tree organizations, students, and teachers to cooperate in a project that builds on the Sacramento Urban Forest Ecosystem Study. This is an opportunity to further refine the ecosystem concept for use by arborists and urban foresters and the people they serve.

\section{Concluding Note}

If urban forest scientists and practitioners are selective about the ecological concepts we bring into urban forestry, we will ensure that we are not simply engaging in a rhetorical exercise that seeks to bring stature but that has little relevance to our practice and constituents. Structure and function are clear and tangible concepts that can be measured with conventional tools. We must further reflect on the concepts of diversity and dominance because they are indices originally developed with a different intent from that of the urban forest researcher and manager. They are, however, descriptive of the richness and balance of urban forest composition and can, under the right circumstances, be useful in public education and even in planning maintenance budgets.

The most powerful aspect of the ecosystem concept is that it requires us to engage in a full accounting of our actions and encourages us to expand our spatial and temporal scales of concern. It forces us to make objective determinations about who benefits and who pays for any modifications to urban forest structure and function. These are tough questions, but the ecological vision that arboriculture and urban forestry have embraced gives us the wherewithal to answer them.

\section{Literature Cited}

Allen-Diaz, B. 1994. Personal communication. Univ. of California, Berkeley.

Anderson, E. 1956. Man as a maker of new plants and new plant communities, pp 763-777. In Thomas, W.L. (Ed). Man's Role in Changing the Face of the Earth. Univ. of Chicago Press, Chicago, IL.

Andresen, J.W. (Ed.). 1976. Trees and Forests for Human Settlements. University of Toronto Center for Urban Forestry Studies. Toronto, Ont. $417 \mathrm{pp}$.

Bassuk, N., and T. Whitlow. 1988. Ecophysiology of urban trees and their management: The North American experience. Hortscience 23:542-546.

Barbour, M.G., J.H. Burke, and W.D. Pitts. 1980. Terrestrial Plant Ecology. Benjamin/Cummings, Menlo Park, CA. 602 pp.

Botkin, D.B. 1990. Discordant Harmonies: A New Ecology for the 21st Century. Oxford Univ. Press, New York, NY, 241 pp.

Bradley, G. (Ed.). 1984. The Urban Forest Interface: Land Use and Forest Resources in a Changing Environment. Univ. of Washington Press, Seattle, WA. 222 pp.

Clark, J.R., N.P. Matheny, G. Cross, and V. Wake. 1997. A model of urban forest sustainability. J. Arboric. 23:17-30.

Costanza, R., B.G. Norton, and B.D. Haskell (Eds.). 1992. Ecosystem Health: New Goals for Environmental Management. Island Press, Washington, DC. 269 p.

Derrenbacher, W.E. 1969. Plants and Landscape: An Analysis of Ornamental Plantings in Four Berkeley Neighborhoods. M.A. thesis, University of California, Berkeley, CA.

Detwyler, T.R. 1972. Vegetation of the city, pp 229259. In Detwyler, T.R., and M.G. Marcus (Eds.). Urbanization and Environment. Duxbury Press, Belmont, CA.

Dwyer, J.F., H.W. Schroeder, and P.H. Gobster. 1994. The deep significance of urban trees and forests, pp 137-150. In Platt, R.H., Rowntree, R.A., and P.C. Muick (Eds.). The Ecological City: Preserving and Restoring Urban Biodiversity. Univ, of Massachusetts Press, Amherst, MA. 
East Bay Hills Vegetation Management Consortium. 1995. Fire Hazard Mitigation Program and Fuel Management Plan for the East Bay Hills. Report prepared by Amphion Environmental, Inc., Oakland, CA.

Forest Ecosystem Management Assessment Team. 1993. Forest Ecosystem Management: An Ecological, Economic, and Social Assessment. Report prepared for USDA Forest Service and other federal agencies.

Gilbert, O.L. 1989. The Ecology of Urban Habitats. Chapman and Hall, London. 369 pp.

Greig-Smith, D. 1983. Quantitative Plant Ecology. Univ. of California Press, Berkeley, CA. 234 pp.

Grey, G.S., and F.J. Deneke. 1978. Urban Forestry. Wiley, New York, NY. 279 pp.

Heisler, G.M. 1986. Effects of individual trees on the solar radiation climate of small buildings. Urban Ecol. 9:337-359.

Heisler, G.M. 1990. Mean wind speed below building height in residential neighborhoods with different tree densities. ASHRAE Transac. 96(1):13891396.

Herrington, L. P. 1980. Preface, p. x-iv. In Hopkins, G. (Ed.). Proceedings, National Urban Forestry Conf, Washington, DC. Nov. 13-16, 1978. SUNY Coll. Envir. Sci. and For., Syracuse, NY.

Hopkins, G. (Ed.). 1980. Proceedings, National Urban Forestry Conference, Washington DC., Nov. 1316, 1978. SUNY Coll. Envir. Sci. and For., Syracuse, NY.

International Society of Arboriculture. 1991. Findings from Research Summit on Urban Ecology. International Society of Arboriculture, Savoy, IL.

Leblanc, F., and D.N. Rao. 1973. Evaluation of the pollution and drought hypothesis in relation to lichens and bryophytes in urban environment. Bryologist. 76:1-19.

Li, H.L. 1969. Urban botany: Need for a new science. Bioscience. 19:882-883.

Lipkis, A. 1997. Personal communication. The Tree People, Los Angeles, CA.

Lowenthal, D. 1965. Introduction, pp x-xxix In Marsh, G.P. (1864) Man and Nature: Or, Physical Geography as Modified by Human Action. Harvard Univ. Press (Belknap), Cambridge, MA (1965).

Marsh, G.P. 1864. Man and Nature: Or, Physical Geography as Modified by Human Action. Harvard Univ. Press (Belknap), Cambridge, MA (1965).

McBride, J., and D. Jacobs. 1975. Urban forest development: A case study, Menlo Park, California. Urban Ecol. 2:1-14.
McBride, J., and D. Jacobs. 1979. Urban forest structure: A key to urban forest planning. Calif. Agric. 33(5):24

McPherson, E.G. 1993. Monitoring urban forest health. J. Environ. Monitor. Assess. 26:165-174.

McPherson, E.G. 1994a. Energy-saving potential of trees in Chicago, pp 95-114. In McPherson, E.G., Nowak, D.J., and R.A. Rowntree (Eds.). 1994. Chicago's Urban Forest Ecosystem: Results of the Chicago Urban Forest Climate Project. USDA For. Serv. Northeast For. Exp. Sta. Gen. Tech. Rpt. NEGTR-186.

McPherson, E.G. 1994b. Benefits and costs of tree planting and care in Chicago, pp 115-134. In McPherson, E.G., Nowak, D.J., and R.A. Rowntree (Eds.). 1994. Chicago's Urban Forest Ecosystem: Results of the Chicago Urban Forest Climate Project. USDA For. Serv. Northeast For. Exp. Sta. Gen. Tech. Rpt. NE-GTR-186.

McPherson, E.G. In press. Structure and sustainability of Sacramento's urban forest. J. Arboric.

McPherson, E.G., D.J. Nowak, and R.A. Rowntree (Eds.). 1994. Chicago's Urban Forest Ecosystem: Results of the Chicago Urban Forest Climate Project. USDA For. Serv. Northeast For. Exp. Sta. Gen. Tech. Rpt. NE-GTR-186.

McPherson, E.G., and R.A. Rowntree. 1989. Using structural measures to compare twenty-two U.S. street tree populations. Landscape J. 8:13-23.

Miller, R.W. 1988. Urban Forestry: Planning and Managing Urban Greenspaces. Prentice-Hall: Englewood Cliffs, NJ. 404 pp.

Moll, G. 1995. Urban ecosystem analysis. In Kollin, C. (Ed). 1995. Proceedings of the 7th National Urban Forest Conference, New York, NY, Sept. 12-16, 1995. American Forests: Washington DC.

Morel, H., and J. Gottmann. 1961. The woodlands, their uses and wildlife, pp 341-383. In Gottmann, J. (Ed.). Megalopolis: The Urbanized Northeastern Seaboard of the United States. Twentieth Century Fund, New York, NY.

Mumford, L. 1956. The natural history of urbanization, pp 382-400. In Thomas, W.L. (Ed.). Man's Role in Changing the Face of the Earth. Univ. of Chicago Press: Chicago, IL.

Nowak, D.J. 1992. Urban Forest Structure and Development: An Analysis of Oakland, CA. Ph.D. dissertation, Dept. of Forestry and Resource Mgt., Univ. of California, Berkeley, CA.

Nowak, D.J. 1994a. Urban forest structure: The state of Chicago's urban forest, pp 3-18. In McPherson, E.G., Nowak, D.J., and R.A. Rowntree (Eds.). 
1994. Chicago's Urban Forest Ecosystem: Results of the Chicago Urban Forest Climate Project. USDA For. Serv. Northeast For. Exp. Sta. Gen. Tech. Rpt. NE-GTR-186.

Nowak, D.J. 1994b. Atmospheric carbon dioxide reduction by Chicago's urban forest, $p p$ 83-94. In McPherson, E.G., Nowak, D.J., and R.A. Rowntree (Eds.). 1994. Chicago's Urban Forest Ecosystem: Results of the Chicago Urban Forest Climate Project. USDA For. Serv. Northeast For. Exp. Sta. Gen. Tech. Rpt. NE-GTR-186. NE-GTR-186.

Nowak, D.J. 1994c. Air pollution removal by Chicago's urban forest, pp 63-82. In McPherson, E.G., Nowak, D.J., and R.A. Rowntree (Eds.). 1994. Chicago's Urban Forest Ecosystem: Results of the Chicago Urban Forest Climate Project. USDA For. Serv. Northeast For. Exp. Sta. Gen. Tech. Rpt. NEGTR-186.

Nowak, D.J. 1996. Estimating leaf area and leaf biomass of open-grown deciduous urban trees. For. Sci. 42(4):504-507.

Nowak, D.J. 1998. Personal communication. Syracuse, NY.

Nowak, D.J., R.A. Rowntree, E. G. McPherson, S.M. Sisinni, E.R. Kerkmann, and J.C. Stevens. 1996. Measuring and analyzing urban tree cover. Landscape and Urban Planning 36:49-57.

Numata, M. 1975. The impact of urbanization on vegetation in Japan, pp 1-11. In Numata, M. (Ed.). Studies in Urban Ecosystems. Chiba Univ., Chiba, Japan.

Platt, R.H., R.A. Rowntree, and P.C. Muick (Eds.). 1994. The Ecological City: Preserving and Restoring Urban Biodiversity. Univ. of Massachusetts Press. Amherst, MA. 291 pp.

Pouyat, R.V., M.J. McDonnell, and S.T.A. Pickett. 1995. The effect of urban environments on soil characteristics in oak stands along an urban-rural land use gradient. J. Envir. Qual. 24:516-526

Richards, N.A. 1993. Reasonable guidelines for street tree diversity. J. Arboric. 19(6):344-349.

Richards, N.A., and J.C. Stevens. 1979. Streetside space and street trees in Syracuse, New York. Ocas. Publ., Coll. of Environmental Science and Forestry, State Univ. of New York: Syracuse. 73 pp.

Rodbell, P.D. (Ed.). 1990. Making Our Cities Safe for Trees: Proceedings of the 4th Urban Forestry Conference, Oct. 15-19, 1989, St. Louis, MO. American Forestry Assoc., Washington DC.

Rowntree, L.B. 1994. Afforestation, fire, and vegetation management in the East Bay Hills of the San Francisco Bay Area. Yearbook of the Association of Pacific Coast Geographers. 56:7-30.
Rowntree, R.A. (Ed.). 1984a. Ecology of the urban forest-1. Urban Ecol. (special issue). 8(1/2):1-178.

Rowntree, R.A. 1984b. Forest canopy cover and land use in four eastern United States cities. Urban Ecol. 8(1/2):55-67.

Rowntree, R.A. (Ed.). 1986. Ecology of the urban forest-II. Urban Ecol. (special issue). 9(3/4):227440.

Rowntree, R.A. (Ed.). 1988. Urban forest ecologyIII. Landscape and Urban Planning (special issue) 15(1-2):1-194.

Rowntree, R.A., G. Greenwood, and R. Marose. 1993. Land use development and forest ecosystems: linking research and management in the Central Sierra, pp 389-398. In Ewert, A.W. , D.J. Chavez, and A. W. Magill (Eds.). Culture, Conflict, and Communication in the Wildland-Urban Interface. Westview Press, San Francisco, CA.

Rowntree, R.A. 1994. Towards ecosystem management: Shifts in the core and context of urban forest ecology, pp 43-59. In Bradley, G.A. (Ed.). Urban Forest Landscapes: Integrating Multidisciplinary Perspectives. Univ. of Washington Press: Seattle, WA.

Sampson, R.N., and R.A. Rowntree. 1992. The living city, pp 16-21. In Rodbell, P.D. (Ed.). Alliance for Community Trees: Proceedings of the Fifth National Urban Forestry Conference, Nov. 15-19, 1991. Los Angeles, CA. American Forestry Assoc. Washington DC.

Schmid, J.A. 1975. Urban vegetation-A review and Chicago case study. Res. Pap. 161. Dept. of Geography, Univ. of Chicago. Chicago, IL.

Seaward, M.R.D. 1979. Lower plants and the urban landscape. Urban Ecol. 4:217-225.

Segal, S. 1969. Ecological Notes on Wall Vegetation. Junk, The Hague, Netherlands. 325 pp.

Stearns, F.W. 1971. Urban botany: An essay on survival. Univ. Wis. Field Stn. Bull. 4(1):1-6.

Sukopp, H., H. Blume, and W. Kunick. 1979. The soil, flora and vegetation of Berlin's waste lands, $\mathrm{pp}$ 115-134. In Laurie, I.C. (Ed.). Nature in Cities. Wiley, New York, NY.

Taoda, H. 1977. Bryophytes in the urban system, pp 99-117. In Numata, M. (Ed.). Interdisciplinary Studies of Urban Ecosystems in the Metropolis of Tokyo. Chiba Univ., Chiba, Japan.

Thomas, W.L. 1956a. Introductory, pp xxi-xxxviii. In Thomas, W.L. (Ed.). Man's Role in Changing the Face of the Earth. Univ. of Chicago Press, Chicago, IL.

Thomas, W.L. (Ed.). 1956b. Man's Role in Changing the Face of the Earth. Univ. of Chicago Press, Chicago, IL. $1193 \mathrm{pp}$. 
Tretheway, R. 1993. Personal communication. Sacramento Tree Foundation, Sacramento, CA.

University of Massachusetts. 1971. Trees and Forests in an Urbanizing Environment. Univ. of Mass. Cooperative Extension Service. Amherst, MA. $178 \mathrm{pp}$.

USDA Forest Service. 1992. Forest Service Research Strategic Plan for the 1990's. USDA Forest Service Research, Washington, DC.

USDA Forest Service. 1993. An Ecosystem Approach to Urban and Community Forestry: A Resource Guide. Northeastern Area, State and Private Forestry, Radnor, PA. 723 pp.

USDA Forest Service. 1994. Briefing by the Chief to the Congressional Committee on Natural Resources, Feb., 1994. USDA Forest Service, Washington, DC.

Waggoner, P.E., and J.D. Ovington (Eds.). 1962. Proceedings of the Lockwood Conference on the Suburban Forest and Ecology. Bull. 652 of the Conn. Agric. Exp. Stn. 102 pp.

Walbridge, M. R. 1997. Urban ecosystems; editorial. Urban Ecosys. 1(1):1-2.

Whitney, G.G., and S.D, Adams. 1980. Man as a maker of new plant communities. J. Appl. Ecol. 17:431448.

Woodwell, G.M., and H.H. Smith (Eds.). 1969. Diversity and Stability in Ecological Systems. Brookhaven Symposium in Biology No. 22, Brookhaven Natl. Lab., Upton, NY. 264 pp.

Woodell, S. 1979. The flora of walls and pavings, pp 135-158. In Laurie, I.C. (Ed.). Nature in Cities. Wiley. New York. NY.

Yaffee, S.L., A.F. Phillips, I.C. Frentz, P.W. Hardy, S.M. Maleki, and B.E. Thorpe. 1996. Ecosystem Management in the United States: An Assessment of Current Experience. Island Press, Washington, DC. $352 \mathrm{pp}$.

Yang, X., G.M. Heisler, M.E. Montgomery, J.H. Sullivan, E.B. Whereat, and D.R. Miller. 1995. Radiative properties of hardwood tree leaves to ultraviolet irradiation. Internat. J. of Biometeorol. 38:60-66.

Zipperer, W.C. 1993. Deforestation patterns and their effects on forest patches. Landscape Ecol. 8(3):177-184.
Acknowledgements. I thank Joe McBride, Scott Stephens, Greg McPherson, Maureen Davis, Laurie Dunn, George Hopkins-Rowntree, and two anonymous reviewers for very helpful suggestions.

\section{Pacific Southwest Research Station USDA Forest Service Berkeley, CA 94701}

Résumé. L'écologie forestière urbaine possède un héritage littéraire de 40 ans. Cette littérature touche à la fois les études courantes de structures, de fonctions, de compositions, de gradients urbain/rural et d'écosystèmes pour donner à l'arboriculture et la foresterie urbaine les statuts de disciplines qui peuvent embrasser l'essentiel de l'écologie et qui peuvent contribuer de faÿon importante aux débats sur les politiques environnementales à l'intérieur et au-delà de la ville traditionnelle. Les concepts réussis d'écologie forestière urbaine ont été recueillis de l'écologie forestière et testés en milieu urbain. Les attributs que sont la structure, la fonction, la diversité, la dominance et la mosaïque de frontières et de gradients servent à décrire les états courants, de changements et futurs de l'écosystème en milieu urbain. Cet article unique donne des exemples et fait progresser le champ de l'écologie forestière urbaine ainsi que notre compréhension de l'écosystème forestier urbain.

Zusammenfassung. Die Stadtforstökologie blickt auf ein intellektuelles Erbe von 40 Jahren bedeutender Literatur zurück. Diese Literatur stellt eine Verbindung zwischen gegenwärtigen Studien über die Struktur, Funktion, Zusammensetzung, Gradienten zwischen urbanen und ländlichen Standorten und über Ökosysteme, die Baumpflege und Forstwirtschaft als Disziplin etablieren, dar. Daraus entsteht ein wichtiger Beitrag zur Umweltpolitik innerhalb und über traditionelle Städte hinaus. Die erfolgreichen Konzepte der urbanen Forstökologie stammen aus der Forstökologie und wurden auf urbanen Standorten getestet. Struktur, Funktion, Artenvielfalt, Dominanz und mosaik-artige Grenzstrikturen sind Attribute, die den gegenwärtigen, sich verändernden und zukünftigen Status der urbanen Forstökologie beschreiben. Diese besondere Veröffentlichung erläutert und fördert das Feld der urbanen Forstökologie und unser Verständnis der urbanen Forstökosysteme. 